\title{
MOTIVACIJA RAĐANJA I SOCIOEKONOMSKI STATUS U CAZINSKOJ KRAJINI
}

\section{SAŽETAK}

Cilj rada je istražiti motiviranost ispitanica Cazinske krajine za rađanjem, $s$ obzirom na postojeće socioekonomsko stanje $i$ stav društva (države) prema trudnoći. Poznatim naučnim metodama napravili smo prospektivno istraživanje (anketiranje) trudnica i žena reproduktivne dobi iz Cazinske krajine (Velika Kladuša i Cazin ), te studentica Pedagoškog fakulteta $i$ Visoke zdravstvene škole Univerziteta u Bihaću. Anketirano je ukupno 1195 ispitanica (trudnice u svim trimestrima trudnoće) - 630 trudnica, 350 žena reproduktivne dobi koje su ostvarile svoju reprodukcije djelomično ili potpuno, 90 studentica Pedagoškog fakulteta koje nisu rađale $i 105$ studentica Visoke zdravstvene škole koje, isto tako, nisu rađale. Anketiranje je provođeno od 1.7. do 30.9. 2008. godine.

Rezultati do kojih smo došli su sljedeći: Prosječna dob ispitanica 23,5 $\pm 2,8$ ili 84,70\% ispitanica nije zaposleno, dok je samo 15,39\% zaposlenih. 47,02\% ispitanica obitavaju u stanu, 28,87\% u porodičnoj kući, a 24,20\% su podstanarke. 52,50\% ispitanica imaju završenu srednju školu, 23,50\% višu školu, 17,77\% osnovnu školu. Svega 6,30\% njih imaju završen fakultet. 48,76\% je prvorotkinja, 47,84\% je drugorotkinja i 3,23\% trećerotkinja. Ispitanica koje su rodile dvoje djece bilo je $82,57 \%$, troje djece $9,14 \%$ i sa jedno dijete 6,85\%. 49,10\% trudnica $i$ žena se izjasnilo kako žele imati samo 2 djece, dok se 49,10\% izjasnilo da nisu motivirane više za trudnoću. $71,79 \%$ studentica se izjasnilo se žele imati samo jedno dijete, dok $72,82 \%$ nije uopće motivirano za trudnoću. 43,76\% ispitanica se izjasnilo kako je nedovoljan interes države za tretman trudnica, a 50,20\% da je briga države za trudnice nikakva. 63,68\% ispitanica promijenilo bi stav oko trudnoće ako bi bilo stimulirajućih mjera, a $30,79 \%$ ne bi mijenjalo svoj stav, bez obzira na potporu. 65,43\%

\footnotetext{
${ }^{1}$ Visoka zdravstvena škola Univerziteta u Bihaću

${ }^{2}$ Dom zdravlja Velika Kladuša, Ginekološka služba - vanbolničko rodilište

${ }^{3}$ Dom zdravlja Cazin, Ginekološka služba - vanbolničko rodilište
} 
ispitanica je nezadovoljno s mjesečnim primanjima koja ne mogu podmiriti njihove potrebe, dok je $23,93 \%$ zadovoljno, pošto im u potpunosti zadovoljavaju životne potrebe.

Na osnovu iznesenoga možemo zaključiti, kako rađanje ovisi o ličnoj motivaciji i stimulaciji države za rađanjem, te izjednačavanjem prava trudnica - bez obzira da li su u procesu rada ili su domaćice na birou.

Ključne riječi: demografska statistika, motivacija, prirodni priraštaj, socioekonomski status.

\section{Uvod}

Reprodukcijsko zdravlje podrazumijeva sposobnost ljudi da imaju zadovoljavajući i siguran spolni život, te sposobnost da se reproduciraju, uz mogućnost i slobodu da odluče hoće li, kada i kako to činiti. Odgađanje rađanja je razlog smanjenja plodnosti žene pojava neplodnosti. Najkvalitetnija reprodukcija žene je između 20. i 30. godine života. U ovome periodu jajne stanice su najkvalitetnije.

Seksualna reprodukcija je biološki proces po kojem organizmi stvaraju potomke kombinacijom genetičkog materijala.

U sagledavanju reproduktivnog zdravlja stanovništva, treba poznavati:

- zdravstvene statističke pokazatelje,

- javni zdravstveni, socijalni i ekonomski nivo populacije,

- kulturu populacije (opću, tehnološku, religijsku i spolnu kulturu).

Reproduktivno zdravlje je usko povezano s populacijskim razvojem kroz navedene ciljeve:

- informacije, edukacije, komunikacije,

- sprječavanja spolno prenosivih bolesti, borbu protiv pandemije AIDS-a,

- smanjenje dječije i maternalne smrtnosti,

- osiguranje tehnologije, istraživanja i razvoja. 
Radna grupa Evropskoga parlamenta i Evropske unije je $\mathrm{u}$ februaru 1999. godine, pokrenula dijalog pet evaluacijskih procesa:

1. važnosti praćenja rasta populacije i održivoga razvoja,

2. očuvanje reprodukcijskog zdravlja,

3. očuvanje spolnog zdravlja,

4. ravnopravnost oba ljudska roda,

5. briga za okoliš.

Svaka žena, prije i u toku trudnoće, porođaja i porodiljstva, besplatno koristi sljedeće usluge javnih zdravstvenih ustanova:

1. savjetovanje prije začeća,

2. periodično praćenje i zdravstvenu njegu u trudnoći,

3. zdravstvenu njegu tokom porođaja,

4. periodično praćenje i zdravstvenu njegu tokom porodiljstva,

5. njegu djeteta.

Sigurno materinstvo je pravo svake žene na njegu, potrebnu za dobro zdravlje od začeća do porođaja. Osnovni elementi potrebni za postizanje sigurnoga materinstva, uključuju visoku kvalitetnu njegu prije trudnoće, u toku trudnoće i nakon porođaja.

Reproduktivno pravo je pravo svih parova i pojedinaca da slobodno i odgovorno odluče o broju, učestalosti i vremenu rađanja svoje djece, kao i da imaju pristup informacijama, edukaciji, komunikaciji i sredstvima koja će im omogućiti da donesu odluku utemeljenu na evidentiranim podacima.

Planiranje porodice je pravo pojedinaca i parova da imaju pristup informacijama; predviđaju i slobodno odlučuju o broju, učestalosti i vremenu rađanja svoje djece.

Agencija za statistiku je objavila Stopu prirodnog priraštaja BiH u 1991. godini koja je iznosila 7,8 promila; 1996. godine 5,9; dok je u 2007. godini ona iznosila 0,1 promila. $\mathrm{U} \mathrm{BiH}$ u 2007. godini rođeno je 33.835 beba, što u odnosu na 2006. godinu pokazuje pad nataliteta za $2,34 \%$, a u odnosu na 1996. godinu pad broja živorođene djece za $28,67 \%$, odnosno rođeno je 13.359 beba manje. 
Stopa nataliteta u BiH 1996. godine iznosila je 12,8 promila, a stopa ukupnoga fertiliteta 1.647. Prošle je godine stopa nataliteta iznosila 8,7 promila, a stopa ukupnoga fertiliteta 1.176 , što je ispod nivoa jednostavne reprodukcije stanovništva. ${ }^{(1)}$

Podaci o mortalitetu pokazuju da opća stopa mortaliteta lagahno raste, zbog povećanja starijeg stanovništva. Stopa mortaliteta 1996. godine je iznosila 6,9 promila, a 2007 . godine 8,8 promila.

Motivacija je sistem motiva koji pokreću čovjeka na raznovrsne intelektualne, emocionalne, socijalne i druge aktivnosti.

Motivi su pokretačka snaga ličnosti u ostvarivanju životnih ciljeva, tako što se oni povezuju sa uloženim naporima u ostvarivanju rezultata.

Motivacija se doživljava kao skup vanjskih i unutarnjih faktora koji podstiču i usmjeravaju određeno ponašanje. ${ }^{(2,3,4,5,5)}$

Osnovne ljudske potrebe prema važnosti su: fiziološke potrebe, potrebe za sigurnošću, potrebe za povezivanjem, potrebe za poštovanjem i potrebe za samopotvrđivanjem.

Kontrola rađanja je naziv za grupu različitih metoda kojima se nastoji ograničiti ili potpuno spriječiti vjerovatnost trudnoće kod žena. ${ }^{(6,7,8,9,10)}$

\section{Cilj rada}

Cilj rada je bio i istražiti motiviranost ispitanica Cazinske krajine za rađanjem, s obzirom na postojeće socioekonomsko stanje i stav društva (države) prema trudnoći.

\section{Ispitanice i metode}

Vršili smo prospektivno istraživanje (anketiranje) trudnica i žena reproduktivne dobi iz Cazinske krajine (Velika Kladuša i Cazin) i studentica Pedagoškog fakulteta i Visoke zdravstvene škole Univerziteta u Bihaću.

Anketirano je ukupno 1.195 ispitanica, trudnica u svim trimestrima trudnoće: 630 trudnica, 350 žena reproduktivne dobi (koje su ostvarile svoju reprodukciju i one koje planiraju rađati), 195 
studentica koje nisu rađale (90 studentica Pedagoškog fakulteta i 105 studentica Visoke zdravstvene škole). Anketiranje je provođeno od 1.7. do 30.9. 2008. godine.

\section{Rezultati istraživanja}

Tabela 1. Broj ispitanica, prosječna dob, zaposlenost i stambene prilike

\begin{tabular}{|c|c|c|c|c|c|c|c|}
\hline \multirow{2}{*}{ ISPITANICE } & \multirow{2}{*}{ Broj } & \multirow{2}{*}{$\begin{array}{c}\text { Prosječna } \\
\text { starosna } \\
\text { dob }\end{array}$} & \multicolumn{2}{|c|}{ Zaposlenost } & \multicolumn{3}{|c|}{ Stambene prilike } \\
\hline & & & DA & $\mathbf{N E}$ & $\begin{array}{c}\text { Porodična } \\
\text { kuća }\end{array}$ & Stan & Podstanar \\
\hline I Trudnice & $\begin{array}{l}650 \\
(54,39 \%)\end{array}$ & $22 \pm 2,5$ & $\begin{array}{c}97 \\
(14,92 \%)\end{array}$ & $\begin{array}{l}553 \\
(85,07 \%)\end{array}$ & $\begin{array}{l}82 \\
(12,61 \%)\end{array}$ & $\begin{array}{c}380 \\
(58,46 \%)\end{array}$ & $\begin{array}{l}188 \\
(28,92 \%)\end{array}$ \\
\hline $\mathrm{II}_{\mathrm{OM}}$ Pacijentice 3 & $\begin{array}{l}350 \\
(29,28 \%)\end{array}$ & $32 \pm 3,4$ & $\begin{array}{c}56 \\
(16,00 \%)\end{array}$ & $\begin{array}{c}294 \\
(84,00 \%)\end{array}$ & $\begin{array}{l}122 \\
(35,03 \%)\end{array}$ & $\begin{array}{c}145 \\
(41,42 \%)\end{array}$ & $\begin{array}{l}83 \\
(23,71 \%)\end{array}$ \\
\hline \multirow{2}{*}{ Ukupno } & \multirow{2}{*}{1000} & \multirow{2}{*}{$27 \pm 2,95$} & \begin{tabular}{|c|}
153 \\
$15,39 \%$ \\
\end{tabular} & \begin{tabular}{|l|}
847 \\
$84,70 \%$ \\
\end{tabular} & \multirow{2}{*}{202} & \multirow{2}{*}{$\begin{array}{l}425 \\
42,50 \%\end{array}$} & \multirow{2}{*}{$\begin{array}{l}271 \\
27,10 \%\end{array}$} \\
\hline & & & \multicolumn{2}{|l|}{$\begin{array}{l}X^{2}=481 \\
P<0,01\end{array}$} & & & \\
\hline \multicolumn{8}{|c|}{ III Studenti } \\
\hline $\begin{array}{l}\text { Pedagoški } \\
\text { fakultet }\end{array}$ & $\begin{array}{l}90 \\
(7,53 \%)\end{array}$ & $20 \pm 2,3$ & - & - & $\begin{array}{l}61 \\
(67,77 \%)\end{array}$ & $\begin{array}{l}15 \\
(16,66 \%)\end{array}$ & $\begin{array}{l}14 \\
(15,55 \%)\end{array}$ \\
\hline $\begin{array}{l}\text { Visoka } \\
\text { zdravstvena škola }\end{array}$ & $\begin{array}{c}105 \\
(8,78 \%)\end{array}$ & $20 \pm 3,1$ & - & - & $\begin{array}{l}80 \\
(76,19 \%)\end{array}$ & $\begin{array}{l}22 \\
(20,95 \%)\end{array}$ & $\begin{array}{l}3 \\
(2,85 \%)\end{array}$ \\
\hline \multirow[b]{2}{*}{ UKUPNO } & \multirow[b]{2}{*}{1.195} & $23,5 \pm 2,8$ & \multirow[b]{2}{*}{ - } & \multirow[b]{2}{*}{ - } & \multirow{2}{*}{$\begin{array}{l}345 \\
(28,87 \%)\end{array}$} & \multirow{2}{*}{$\begin{array}{c}562 \\
(47,02 \%)\end{array}$} & \multirow{2}{*}{$\begin{array}{c}288 \\
(24,10 \%)\end{array}$} \\
\hline & & $\begin{array}{l}X^{2}=0.32 \\
p>0,05\end{array}$ & & & & & \\
\hline
\end{tabular}

1195 ispitanica s prosječnom dobi 23,5 $\pm 2,8: 84,70 \%$ su nezaposlene, $47,20 \%$ stanuje u vlastitome stanu, $28,87 \%$ u porodičnim kućama i $24,10 \%$ su podstanarke. U istraživanju su najviše obuhvaćene trudnica koje su činile 54,39\% anketiranoga uzorka. 
Statistički je značajan veći broj nezaposlenih pacijenticu u odnosu na zaposlene. $\left(X^{\mathbf{2}}=\mathbf{4 8 1}=\mathbf{P}<\mathbf{0 , 0 1}\right)$

Tabela 2. Školska sprema trudnica i žena reproduktivne dobi

\begin{tabular}{|c|c|c|c|c|c|}
\hline \multirow{2}{*}{$\begin{array}{c}\text { ISPITANI } \\
\text { CE }\end{array}$} & \multirow{2}{*}{ Broj } & \multicolumn{4}{|c|}{ Školska sprema } \\
\hline & & OŠ & SSS & V̌SS & VSS \\
\hline I Trudnice & 650 & 87 & 340 & 180 & 43 \\
\hline $\begin{array}{c}\text { II } \\
\text { Pacijentice } \\
\text { OM }\end{array}$ & 350 & 90 & 185 & 55 & 20 \\
\hline \multirow[t]{2}{*}{ UKUPNO } & 1000 & $\begin{array}{c}177 \\
(17,77 \%)\end{array}$ & $\begin{array}{c}525 \\
(52,50)\end{array}$ & $\begin{array}{c}235 \\
(23,50 \%)\end{array}$ & $\begin{array}{c}63 \\
(6,30 \%)\end{array}$ \\
\hline & \multicolumn{5}{|c|}{1000} \\
\hline
\end{tabular}

$52,50 \%$ žena ima završenu srednju školu, $23,50 \%$ višu školu, $17,77 \%$ je sa osnovnom školom i svega $6,30 \%$ je sa završenim fakultetom.

Tabela 3. Redoslijed trudnoća i broj poroda

\begin{tabular}{|c|c|c|c|c|c|}
\hline \multirow{2}{*}{ ISPITANICE } & \multicolumn{4}{|c|}{ A) $T r u d n o c ́ a$} & \multirow[t]{2}{*}{ UKUPNO } \\
\hline & Prva & Druga & Treća & Četvrta & \\
\hline $\begin{array}{c}\text { I Trudnice } \\
650\end{array}$ & 317 & 311 & 21 & 1 & 650 \\
\hline Postotak & $(48,76 \%)$ & $(47,84 \%)$ & $(3,23 \%)$ & $(0,15 \%)$ & $(100,00 \%)$ \\
\hline Broj pobačaja & $\begin{array}{c}11 \\
(3,47 \%) \\
\end{array}$ & $\begin{array}{c}7 \\
(2,25 \%) \\
\end{array}$ & $\begin{array}{c}16 \\
(76,19 \%) \\
\end{array}$ & - & $5,23 \%$ \\
\hline \multirow{2}{*}{$\begin{array}{c}\text { II Pacijentice OM } \\
350\end{array}$} & \multicolumn{4}{|c|}{ Broj poroda } & \\
\hline & 1 & 2 & 3 & 4 & \multirow{2}{*}{350} \\
\hline Broj & 24 & 289 & 32 & 5 & \\
\hline Postotak & $(6,85 \%)$ & $(82,57 \%)$ & $(9,14 \%)$ & $(1,42 \%)$ & $(100,00 \%)$ \\
\hline \multirow{2}{*}{ Broj pobačaja } & $\begin{array}{c}7 \\
(29,16 \%)\end{array}$ & $\begin{array}{c}31 \\
(10,72 \%)\end{array}$ & \multirow[b]{2}{*}{ - } & \multirow[b]{2}{*}{ - } & \multirow{2}{*}{$(10,57 \%)$} \\
\hline & $\begin{array}{l}\text { Ab) I i II } \\
p>(\end{array}$ & $\begin{array}{l}X^{2}=0,22 \\
05\end{array}$ & & & \\
\hline
\end{tabular}


Od 650 trudnica prvorotkinja je 48,76\%, drugorotkinja 47,84\%, trećerotkinja $3,23 \%$, sa $5,23 \%$ pobačaja u istraživanoj skupini. 350 je žena reproduktivne dobi koje su imale dva poroda ili $82,57 \%$, sa tri 9,14\% i sa jednim porodom 6,85\%; zastupljenost pobačaja 10,57\%. Nema statističkog značaja u broju abortusa kod istraživanih pacijentica - trudnica i netrudnica. $\left(\mathbf{X}^{2}=\mathbf{0 , 2 2} ; \mathbf{p}>\mathbf{0 , 0 5}\right)$

Tabela 4. Stav o broju djece i motiviranosti za narednu trudnoću

\begin{tabular}{|c|c|c|c|c|c|c|}
\hline \multirow{2}{*}{ ISPITANICE } & \multicolumn{3}{|c|}{ Stav za broj djece } & \multicolumn{3}{|c|}{$\begin{array}{c}\begin{array}{c}\text { Motiviranost za slijedeću } \\
\text { trudnoću }\end{array} \\
\end{array}$} \\
\hline & 1 & 2 & 3 & DA & NE & $\begin{array}{c}\text { Ne zna } \\
\text { (dvojba) }\end{array}$ \\
\hline $\begin{array}{l}\text { I Trudnice } \\
\quad 650\end{array}$ & 285 & 302 & 63 & 401 & 215 & 34 \\
\hline $\begin{array}{c}\text { II Pacijentice OM } \\
350\end{array}$ & 146 & 189 & 15 & 24 & 276 & 50 \\
\hline \multirow[b]{2}{*}{$\begin{array}{l}\text { UKUPNO } \\
1000\end{array}$} & \multirow[b]{2}{*}{$\left|\begin{array}{c}431 \\
(43,10 \%)\end{array}\right|$} & \multirow[b]{2}{*}{$\begin{array}{c}491 \\
(49,10 \%)\end{array}$} & \multirow[b]{2}{*}{$\begin{array}{c}78 \\
(7,80 \%)\end{array}$} & \begin{tabular}{|c|}
425 \\
$(42,50 \%)$ \\
\end{tabular} & $\begin{array}{c}491 \\
(49,10 \%)\end{array}$ & \multirow[b]{2}{*}{$\begin{array}{c}84 \\
(8,40 \%)\end{array}$} \\
\hline & & & & \multicolumn{2}{|c|}{$\begin{array}{c}X^{2}=4,76 \\
\text { Tablica vrijedi } \\
3,81=* p<0,05\end{array}$} & \\
\hline \multicolumn{4}{|c|}{ III Studenti } & \multicolumn{3}{|c|}{$\begin{array}{l}\text { Motiviranost uopće za } \\
\text { trudnoće }\end{array}$} \\
\hline \multirow{2}{*}{$\begin{array}{l}\text { Pedagoški } \\
\text { fakultet } \\
90\end{array}$} & \multirow{2}{*}{67} & \multirow{2}{*}{13} & \multirow{2}{*}{10} & $\mathrm{Da}$ & $\mathrm{Ne}$ & \begin{tabular}{|c|c|}
$\begin{array}{c}\text { Nije } \\
\text { razmišljala }\end{array}$ \\
\end{tabular} \\
\hline & & & & 11 & 64 & 15 \\
\hline \begin{tabular}{|c|} 
Visoka \\
zdravstvena škola \\
105 \\
\end{tabular} & 73 & 27 & 5 & 19 & 78 & 8 \\
\hline \multirow[t]{2}{*}{ U K U P N O } & $\begin{array}{c}140 \\
(71,79 \%)\end{array}$ & $\begin{array}{c}40 \\
(20,51 \%)\end{array}$ & $\begin{array}{c}15 \\
(7,69 \%)\end{array}$ & $\begin{array}{c}30 \\
(15,38 \%)\end{array}$ & $\begin{array}{c}142 \\
(72,82 \%)\end{array}$ & $\begin{array}{c}23 \\
(11,79 \%)\end{array}$ \\
\hline & $\begin{array}{c}X^{2}=0 \\
26 \\
p>0,05\end{array}$ & & & \multicolumn{2}{|c|}{$\begin{array}{c}\mathrm{X}^{2}=72,93 \\
\text { Tablica vrijedi } \\
6,63=* * \mathrm{P}<0,01\end{array}$} & \\
\hline
\end{tabular}

$49,10 \%$ trudnica izjasnilo se da žele imati dvoje djece, $43,10 \%$ jedno dijete, i 7,80\% troje ili više djece. Kod trudnica je motiviranost za sljedeći porod $49,10 \%$ nemotivirano, $42,50 \%$ motivirano. 
Kod studentica $71,79 \%$ se izjasnilo kako žele jednom roditi, $20,51 \%$ žele imati dvoje djece, svega $7,69 \%$ žele imati troje djece. U trenutku anketiranja $72,82 \%$ nije bilo motivirano za trudnoću, dok je svega $15,38 \%$ motivirano. $10,00 \%$ nije se moglo izjasniti o motiviranosti za trudnoću. Statistički je značajna nemotiviranost za rađanjem u odnosu na ispitanice koje žele rađati. $\left(X^{2}=\mathbf{4 , 7 6}\right.$, tablica vrijedi $3,81=* \mathbf{p}<0,05 ; X^{2}=72,93$ tablica vrijedi $\left.6,63=* * P<0,01\right)$

Tabela 5. Mišljenje o potpori države za stimulaciju rađanja

\begin{tabular}{|c|c|c|c|c|}
\hline \multirow{2}{*}{ ISPITANICE } & \multirow{2}{*}{ Broj } & \multicolumn{3}{|c|}{ Odnos države prema trudnicama } \\
\hline & & Dobar & Nedovoljan & Nikakav \\
\hline I Trudnice & 650 & 43 & 312 & 295 \\
\hline II Pacijentice OM & 350 & 24 & 37 & 289 \\
\hline \multirow[b]{2}{*}{ Ukupno I, II } & \multirow[b]{2}{*}{1000} & $\begin{array}{c}67 \\
(67 \%)\end{array}$ & $\begin{array}{c}349 \\
(3490 \%)\end{array}$ & \multirow[b]{2}{*}{$\begin{array}{c}584 \\
(58,40 \%)\end{array}$} \\
\hline & & \multicolumn{2}{|c|}{$\begin{array}{c}\mathrm{X} 2=191 \text { tablica vrijedi } \\
6.63 \\
\mathrm{P}<0,01\end{array}$} & \\
\hline III Studenti & & & & $\begin{array}{l}\text { I, II i III X2 } \\
\quad=0,22 \\
\quad p>0,05\end{array}$ \\
\hline Pedagoški fakultet & 90 & - & 88 & 2 \\
\hline $\begin{array}{c}\text { Visoka zdravstvena } \\
\text { škola }\end{array}$ & 105 & 5 & 86 & 14 \\
\hline \multirow[b]{2}{*}{ Ukupno III } & \multirow[b]{2}{*}{195} & $\begin{array}{c}5 \\
(2,56 \%)\end{array}$ & $\begin{array}{c}174 \\
(89,23 \%)\end{array}$ & \multirow[b]{2}{*}{$\begin{array}{c}16 \\
(8,20)\end{array}$} \\
\hline & & \multicolumn{2}{|c|}{$\begin{array}{c}\mathrm{X}^{2}=159 \\
\text { tabela vrijedi } \\
6,63 \\
\mathrm{P}<0,01\end{array}$} & \\
\hline \multirow{3}{*}{ UKUPNO I, II, III } & \multirow{2}{*}{1195} & 72 & 523 & 600 \\
\hline & & $(6,02 \%)$ & $(43,76 \%)$ & $(50,20 \%)$ \\
\hline & & \multicolumn{2}{|c|}{$\begin{array}{c}\text { Dobra -nedovoljna } \\
\mathrm{X} 2=341 \\
\text { tabela vrijedi } 6,63 \\
* * \mathrm{P}<0,01\end{array}$} & $\begin{array}{c}\text { Nedovoljna } \\
\text {-nikakva } \\
\mathrm{X} 2=5,28 \\
\text { tabela } \\
\text { vrijedi } \\
3,84 \mathrm{p}<0,05\end{array}$ \\
\hline
\end{tabular}


Kod stimulacije (potpore) države za stimulaciju rađanja 43,76\% ispitanica se izjasnilo da je ona nedovoljna, 50,20\% da je tretman nikakav, a svega $6,02 \%$ izjasnilo se da je potpora dobra. Statistički značajna je nemotiviranost povezana s nedovoljnom brigom društva prema trudnoći i trudnicama.

Tabela 6. Promjene stava uvođenjem naknade, stimulativnih mjera rađanja

\begin{tabular}{|c|c|c|c|c|}
\hline \multirow[b]{2}{*}{ ISPITANICE } & \multirow[b]{2}{*}{ Broj } & \multicolumn{3}{|c|}{$\begin{array}{c}\text { Stimulativne mjere države } \\
\text { (promjene stava) }\end{array}$} \\
\hline & & $\begin{array}{l}\text { Promijenili } \\
\text { bi stav }\end{array}$ & $\begin{array}{c}\text { Ne bi } \\
\text { Promijenili } \\
\text { stav }\end{array}$ & Ne znam \\
\hline I Trudnice & 650 & 390 & 207 & 53 \\
\hline II Pacijentice OM & 350 & 222 & 120 & 8 \\
\hline \multirow[b]{2}{*}{ UKUPNO I,II } & \multirow[b]{2}{*}{1000} & $\begin{array}{c}612 \\
(61,20 \%)\end{array}$ & $\begin{array}{c}327 \\
(32,70 \%)\end{array}$ & \multirow[b]{2}{*}{$61(6,10 \%)$} \\
\hline & & \multicolumn{2}{|c|}{$\begin{array}{c}\mathrm{X}^{2}=86,5 \\
\text { tabela vrijedi } \\
3,84 \\
\mathrm{P}<0,05\end{array}$} & \\
\hline \multicolumn{5}{|c|}{ III Studenti } \\
\hline Pedagoški fakultet & 90 & 70 & 18 & 2 \\
\hline $\begin{array}{c}\text { Visoka zdravstvena } \\
\text { škola }\end{array}$ & 105 & 79 & 23 & 3 \\
\hline \multirow[b]{2}{*}{ UKUPNO III } & \multirow[b]{2}{*}{195} & $\begin{array}{c}149 \\
(76,41 \%)\end{array}$ & $\begin{array}{c}41 \\
(21,02 \%)\end{array}$ & \multirow[b]{2}{*}{$\begin{array}{c}5 \\
(2,56 \%)\end{array}$} \\
\hline & & \multicolumn{2}{|c|}{$\begin{array}{c}\mathrm{X}^{2}=61,39 \\
\text { tablica vrijedi } 3,84 \\
\mathrm{P}<0,05\end{array}$} & \\
\hline \multirow[b]{2}{*}{ UKUPNO I,II,III } & \multirow[b]{2}{*}{1195} & $\begin{array}{c}761 \\
(63,68 \%)\end{array}$ & $\begin{array}{c}368 \\
(30,79 \%)\end{array}$ & \multirow{2}{*}{$\begin{array}{c}66 \\
(5.53 \%)\end{array}$} \\
\hline & & $\begin{array}{r}\mathrm{X}^{2}= \\
\text { tablica } \mathrm{V} \\
\mathrm{P}<\end{array}$ & $\begin{array}{l}36,8 \\
\text { jedi } 3,84 \\
05\end{array}$ & \\
\hline
\end{tabular}


Uvođenjem naknada i drugih stimulativnih mjera države $63,68 \%$ ispitanica bi promijenilo svoj stav, dok bi 30,79\% zadržale svoje mišljenje a 5,53\% ne zna da li bi promijenili stav, ili bi ostali kod već izrečenoga. Ako bi postojala stimulacija države za rađanjem, statistički bi značajno ispitanice promijenile svoj stav o rađanju.

$\left(X^{2}=86,5\right.$ tablica vrijedi $3,84, P<0,05 ; \quad X^{2}=61,39$ tablica vrijedi 3,84, $\mathrm{P}<0,05$ )

Tabela 7. Zadovoljenje potreba porodice novčanim mjesečnim primanjima

\begin{tabular}{|c|c|c|c|}
\hline \multirow[t]{2}{*}{ ISPITANICE } & \multicolumn{3}{|c|}{$\begin{array}{c}\text { Zadovoljenje potreba mjesečnim } \\
\text { primanjima }\end{array}$} \\
\hline & DA & NE & Djelomično \\
\hline $\begin{array}{l}\text { I Trudnice } \\
650\end{array}$ & $\begin{array}{c}147 \\
(22,61 \%)\end{array}$ & $\begin{array}{c}430 \\
(66,15 \%)\end{array}$ & $\begin{array}{c}73 \\
(11,23 \%)\end{array}$ \\
\hline $\begin{array}{l}\text { II Pacijentice OM } \\
350\end{array}$ & $\begin{array}{c}59 \\
(16,85 \%)\end{array}$ & $\begin{array}{c}287 \\
(82,00 \%)\end{array}$ & $\begin{array}{c}4 \\
(1.14 \%)\end{array}$ \\
\hline \multirow[b]{2}{*}{ UKUPNO I, II } & $\begin{array}{c}206 \\
(20,60 \%)\end{array}$ & $\begin{array}{c}717 \\
(71,70 \%)\end{array}$ & \multirow[b]{2}{*}{$77(7,70 \%)$} \\
\hline & \multicolumn{2}{|c|}{$\begin{array}{c}\mathrm{X}^{2}=282 \\
\text { Tabela vrijedi } 3,84 \\
\mathrm{P}<0,05\end{array}$} & \\
\hline \multicolumn{4}{|c|}{ III Studenti } \\
\hline $\begin{array}{l}\text { Pedagoški fakultet } \\
90\end{array}$ & $\begin{array}{c}31 \\
(34,44 \%)\end{array}$ & $\begin{array}{c}27 \\
(30,00 \%)\end{array}$ & $\begin{array}{c}32 \\
(35,55 \%)\end{array}$ \\
\hline $\begin{array}{c}\text { Visoka zdravstvena škola } \\
105 \\
\end{array}$ & $\begin{array}{c}49 \\
(46,66 \%) \\
\end{array}$ & $\begin{array}{c}38 \\
(36,19 \%) \\
\end{array}$ & $\begin{array}{c}18 \\
(17,14 \%) \\
\end{array}$ \\
\hline \multirow{2}{*}{ Ukupno III } & $\begin{array}{c}80 \\
(41,02 \%) \\
\end{array}$ & $\begin{array}{c}65 \\
(33,33 \%) \\
\end{array}$ & \multirow{2}{*}{$50(25,64 \%)$} \\
\hline & & & \\
\hline \multirow[b]{2}{*}{ UKUPNO 1195} & $\begin{array}{c}286 \\
(23,93 \%)\end{array}$ & $\begin{array}{c}782 \\
(65,43 \%)\end{array}$ & \multirow{2}{*}{$\begin{array}{c}127 \\
(10,62 \%)\end{array}$} \\
\hline & $\begin{array}{r}\mathrm{X}^{2} \\
\text { tablica } \\
\mathrm{P}<\end{array}$ & di 6,63 & \\
\hline
\end{tabular}


$65,43 \%$ ispitanica ne može podmiriti svoje potrebe u porodici; $23,93 \%$ se izjasnilo da mogu primanjima podmirivati svoje potrebe, a djelomično da može zadovoljiti svoje potrebe izjasnilo se 10,62\% ispitanica. Statistički gledano primanja ispitanica ne mogu zadovoljiti njihove potrebe. $\left(\mathrm{X}^{2}=\mathbf{2 3 0}\right.$ tabela vrijedi $\left.\mathbf{6 , 6 3}, \mathbf{P}<\mathbf{0 , 0 1}\right)$

\section{Zaključak}

Istraživanja su pokazala da je briga društva u cjelini nedovoljna za stimulaciju rađanja: $43,70 \%$ je izjavilo da je nedovoljna briga države, a 50,20\% da je nikakva; $63,20 \%$ promijenilo bi stav o rađanju ako bi postojale stimulativne mjere (finansijska potpora, izjednačavanje prava trudnica bez obzira na zaposlene ili nezaposlene).

Ako bi postojala stimulacija države za rađanjem, statistički značajno bi ispitanice promijenile svoj stav o rađanju.

Trudnice i žene koje su rađale, njih $49,10 \%$ želi imati samo dvoje djece, dok 50,20\% studentica žele imati samo jedno dijete.

Država kao makrosistem mora podsticati i stimulirati sve oblike motivacije, tj. mora dati strateški impuls generiranju motivatora, pošto je u BiH u 2007. godini rođeno svega 33.835 beba, što u odnosu na 2006. godinu pokazuje pad nataliteta za 2,34\%, a u odnosu na 1996. godinu pad broja živorođene djece za $28,67 \%$, odnosno rođeno je 13.359 beba manje.

Strategija podizanja nataliteta, temelji se na životu, porodici i djeci kao temeljnim vrijednostima društva.

WHO je objavila podatak kako stopa rađanja iznosi 1,73 djeteta na jednu ženu.

\section{Literatura:}

1. Agencija za statistiku Bosne i Hercegovine, 2008. (www.bhas.ba)

2. Chesnais, J. C., The Demographic Transition: Stages, Patterns and Economic Implications, translation E. Kreager and P. Kreager, Oxford, 1992: Clarendon Press.

3. Demographic transition, Encyclopedia of Population 1., Macmillan Reference, 507., 2003. ISBN 0-02-865677-6., P 211 
4. Dražančić A. - Benjak V. -Blašković-Kokez J. - Čuržik D. - Bucat M. Filipović-Grčić B., et al., Plan i program perinatalne zaštite u Hrvatskoj, 2008., Gynaecol Perinatol, 17/101-116.

5. Gardiner, G. \& Bourke, E., Indigenous populations, 'mixed' discourses and identities, People and Place 8/2, 2000., 43-52.

6. Hugo, G., Declining fertility and policy intervention in Europe: Some lessons for Australia?, Journal of Population Research, 17/2, 2000., 175-197.

7. Paffenbarger, R. S. - Hyde, R. T. - Wing, A. L. - Hsieh, C. C., Physical activity, all-cause mortality, and longevity of college alumni, New England Journal of Medicine 314., 1986., P 605 - 613.

8. Petersen, G., Gray dawn. The global aging crisis, in F. Moulder (ed.), Social Problems of the Modern World, Wadsworth/Thomson, Australia, 2000., PP 126134.

9. Wilson, C., Implications of global demographic convergence for fertility theory, paper presented to the International Union for the Scientific Study of Population Working Group on Low Fertility, International Perspectives on Low Fertility: Trends, Theories and Policies, 21-23 March, 2001.

10. World Health Organization, World Health Statistics 2007., WHO, Geneva, 2007. 
PROF. DR. Sulejman Kendić, P.H.D., Šemso Rošić i Mirsad Avdić

\section{SOCIAL - ECONOMIC STATUS AND MOTIVATION FOR GIVING BIRTH IN CAZIN REGION}

\section{SUMMARY}

The goal of this paper is to research the motivation of women for giving birth in Cazin region concerning the social-economic status and at the attitude of society to giving birth.

The research was done on the pregnant women and women in the reproductive age who live in Cazin region ( V.Kladuša and Cazin) as well as the students of Pedagogic High School and Medical High School in the Bihać University. The total of 1195 patients was polled. Out of them 630 were pregnant, 350 of them were the women in the reproductive age and the 90 students from the Pedagogic High School who didn't give the birth as well as the 105 students from the Medical High School. The pool was conducted from $1^{\text {st }}$ July to $30^{\text {th }}$ September 2008. Results: The patients' average age was $23,5 \pm 2,8.84,70 \%$ of them were not employed and the 15,39\% were employed. $47,02 \%$ live in the apartment, $28,87 \%$ live in the family house and the rest of them, $24,20 \%$, live in the rented houses and flats. $52,50 \%$ of them have finished the primary school, $23,50 \%$ have finished the high school and $6,30 \%$ have finished the university. $48,76 \%$ of them have one child, $47,84 \%$ have two children and the 3,23\% have three children. $49,10 \%$ of them said that they want to have only two children and $49,10 \%$ of them said that they are not motivated to have children. $71,79 \%$ of the students said that they want to have only one child and $72,82 \%$ of them don't want to have any children. $43,76 \%$ of the patients don't see enough support from the country during the birth and after, 50,20\% of the patients don't see any kind of the support from the country. $63,68 \%$ of the patients would have children if the state changed the law and the $30,79 \%$ of them wouldn't have the children at all. $65,43 \%$ of the patients think that they don't have enough money for themselves because of the economic situation, while the $23,93 \%$ think the opposite. 
Conclusion: Giving birth depends on the personal motivation and the state stimulation regardless of whether they work or are at the home as the housewives.

Key words: demographic statistic, motivation, social-economic status, population increase. 
الأستاذ الدكتور سليمان كينديتش، شيمسو روشيتش، مرصاد عفديتش

الحالة الاجتماعية الاقتصادية وتحفيز على الولادة في منطقة تسازينسكا كرايينا

\section{(Cazinska Krajina)}

\section{خلاصة البحث}

هدف البحث: بحث تحفيز من شملهم الاستبيان من نساء منطقة تسازينسكا كرايينا

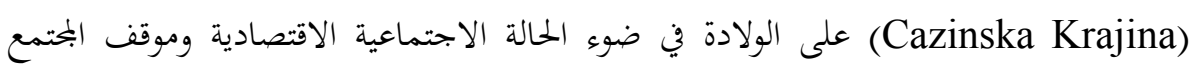

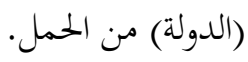

من شمله الاستبيان ومنهج البحث: دراسة تقديرية (الاستطلاع) للحوامل والنساء

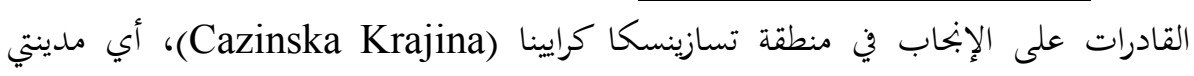

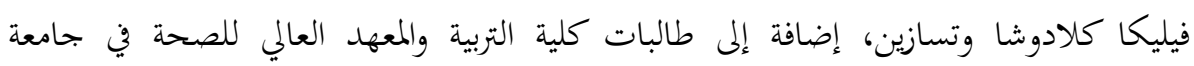

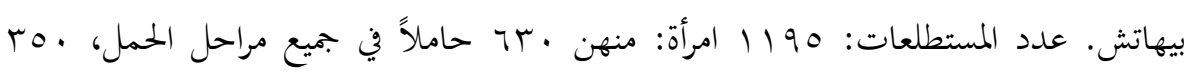

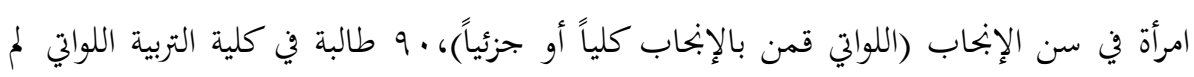

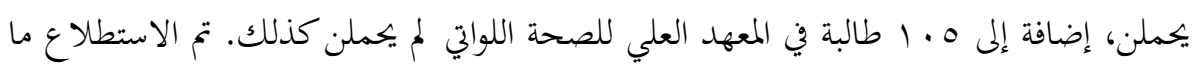

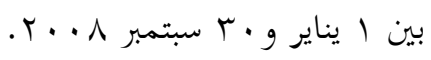

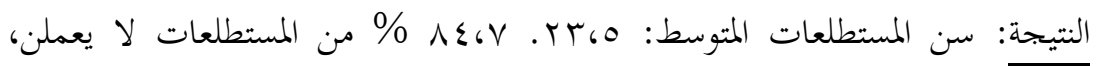

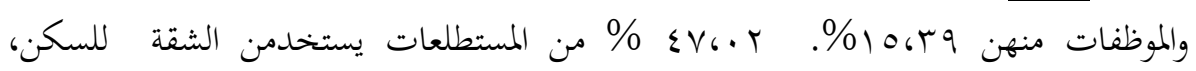
\% YA،AV

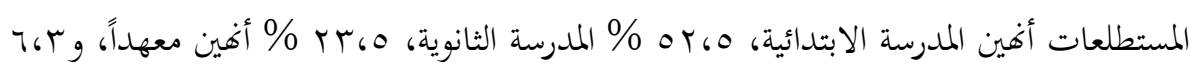
\% أغين المرحلة الجامعية.

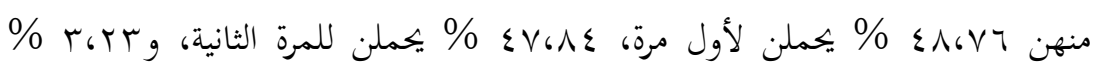

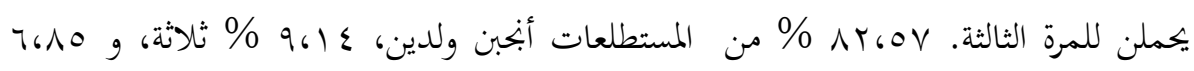

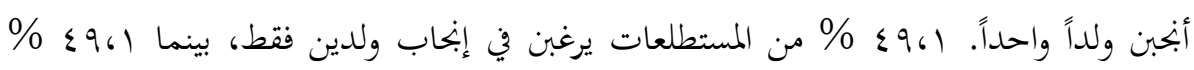

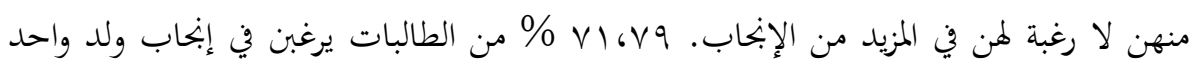

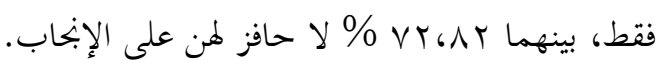


\% \% من المستطلعات يرين أن الدولة ليس لديها مسؤولية تجاه وضع المرأة الحامل،

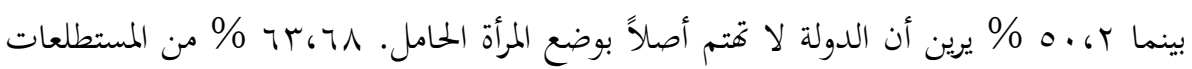

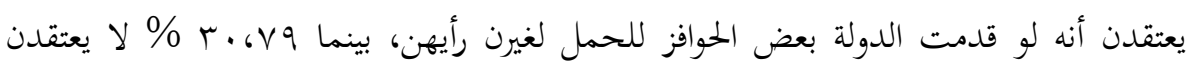

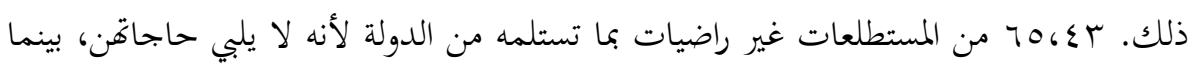

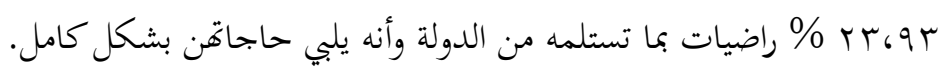

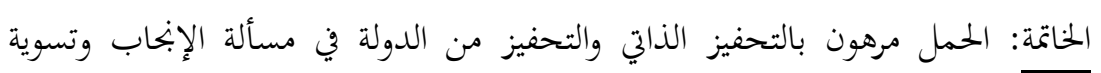
وضع وحقوق الحوامل، سواء كن عاملات، ربات بيوت أو ينتظرن العمل.

الكلمات الرئيسة: الإحصاء الديموغرافي، التزايد الطبيعي، التحفيز، الحالة الاجتماعية الاقتصادية 